\title{
The National Flood-Frequency Program-Methods for Estimating Flood Magnitude and Frequency for Non-tidal Streams in Delaware, 2001
}

\section{Introduction}

Estimates of the magnitude and frequency of flood-peak discharges and flood hydrographs are used for a variety of purposes, such as for the design of bridges, culverts, and flood-control structures; and for the management and regulation of flood plains. To provide simple methods of estimating flood-peak discharges, the U.S. Geological Survey (USGS) has developed and published regression equations for every State, the Commonwealth of Puerto Rico, American Samoa and a number of metropolitan areas in the United States. In 1993, the USGS, in cooperation with the Federal Emergency Management Agency and the Federal Highway Administration, compiled all current USGS statewide and metropolitan area regression equations into a computer program, titled "The National Flood-Frequency (NFF) Program" (Jennings and others, 1994).

Since 1993, new or updated regression equations have been developed by the USGS for various areas of the Nation. These new equations have been incorporated into an updated version of the NFF Program.

This Fact Sheet describes the application of the updated NFF Program to streams that drain non-tidal streams in Delaware. Fact sheets that describe application of the updated NFF Program to various other areas of the Nation are available.

\section{Overview}

Delaware is divided into two hydrologic regions, the Piedmont and the Coastal Plain, on the basis of physiography. The boundary between the regions is defined by the Fall Line in figure 1.
Dillow (1996) developed regression equations for estimating peak discharges $\left(\mathrm{Q}_{\mathrm{T}}\right)$, in cubic feet per second, having recurrence intervals $(T)$ ranging from 2 to 500 years. The regression equations are not applicable at sites affected by peak-discharge regulation because of dams, tides at marshes, excavation, mining, or landfill activities.

The regression equations were developed using peak-discharge data from 33 streamgaging stations in Delaware, 23 streamgaging stations in Maryland, and 18 streamgaging stations in Pennsylvania. All stations used to develop the equations had at least 10 years of record compiled from the early 1980's to the latter part of 1990.

Recurrence interval is the reciprocal of the annual exceedance probability, and represents the average number of years between peak discharges of the same or greater magnitude. For example, the 100-year flood occurs, on average, once in 100 years, and has a 0.01 exceedance probability. This does not imply that the 100year flood will be exceeded each 100 years, but that it has a 1 percent probability of occurring in any given year.

\section{Procedure}

The equations are based on the inch-pound system of units, but the NFF Program will accept and report either the inch-pound or metric system of units. The explana- tory watershed variables used in the regression equations are as follows:

Drainage area (A), in square miles, is the total area that contributes runoff upstream of the stream site of interest, and is determined from USGS 7.5-minute series topographic quadrangle maps.

Basin development factor (BDF), ranging from 0 to 12 , is an index of development based on improvements to the basin drainage system (Sauer and others,

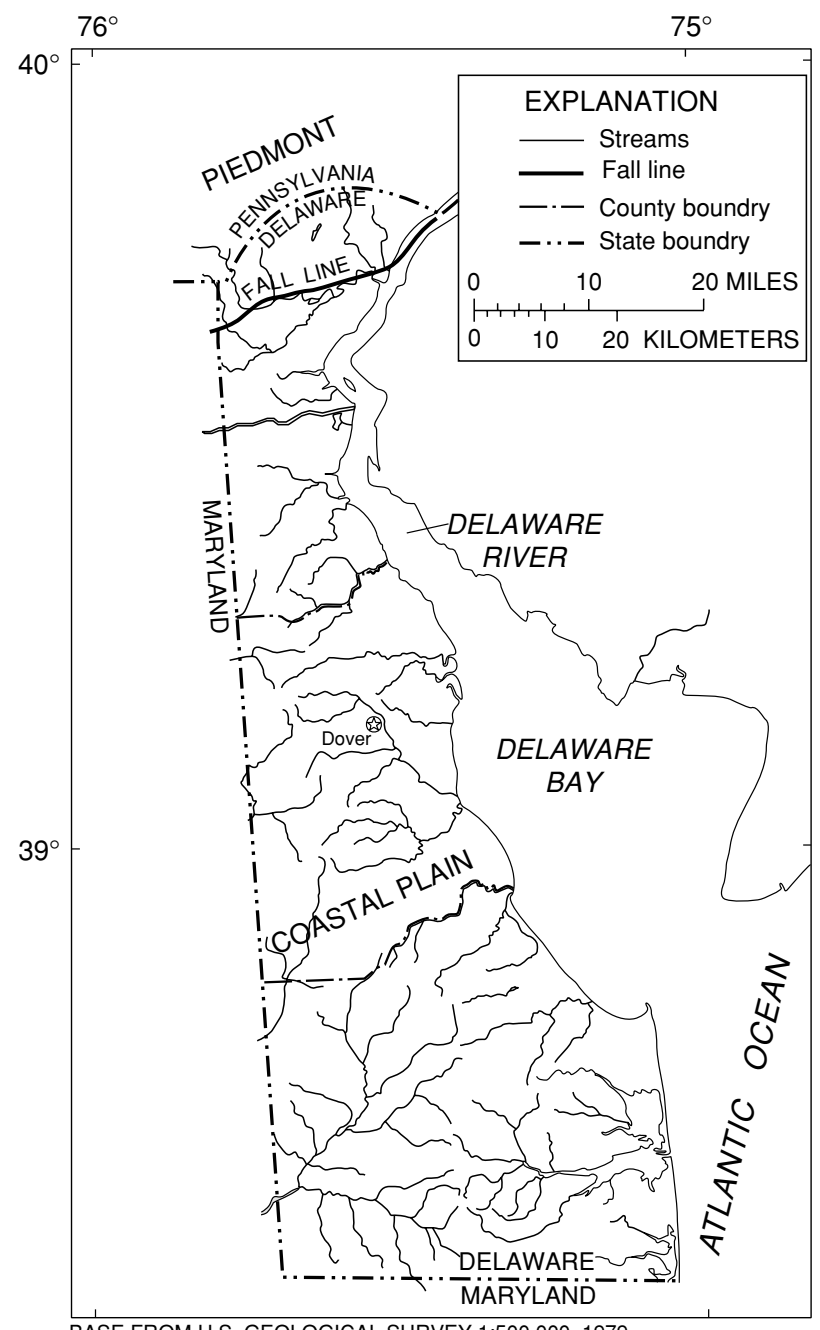

SE FROM U.S. GEOLOGICAL SURVEY 1:500,000, 1979

Figure 1. Hydrologic regions of Delaware. 
1983). The BDF is determined by first dividing the basin into upper, middle, and lower thirds such that each subarea contains approximately one-third of the total basin area and the travel distances of streams within a given third are approximately equal (this does not mean the travel distances of streams in different thirds are equal). A value of 0 or 1 is assigned to each subarea for each of the following four development categories:

Curb-and-gutter streets.-If more than 50 percent of a basin-third subarea has residential, commercial, or industrial development, individually or in combination, and if more than 50 percent of the roadways in the subarea have curb-and-gutter construction, then a code 1 is assigned for that category in the subarea; otherwise, a code 0 is assigned.

Storm drains (storm sewers).--If more than 50 percent of the secondary tributaries in a subarea exist as enclosed drainage structures, such as storm drains and storm sewers, then a code 1 is assigned to this category; otherwise, a code 0 is assigned.

Channel improvements.-If more than 50 percent of the combined lengths of the main drainage channel and the principal tributaries have been straightened, enlarged, deepened, cleared, and (or) have other improvements, then a code 1 is assigned to this category in the subarea; otherwise, code 0 is assigned.

Channel linings.-If more than 50 percent of the combined lengths of the main drainage channel and the principal tributaries have been lined with an impervious material, then a code 1 is assigned to this category in the subarea; otherwise, a code 0 is assigned.

The sum of the values assigned to the four development categories for each subarea is the BDF. Values assigned to development categories can be determined from field inspection, or from available or planned zoning maps or planning documents. The BDF is subtracted from a constant of 13 by the NFF program; the user enters the actual value of BDF.

Storage (ST), is the percentage of drainage area, A, that is covered by lakes, ponds, or swamps. On USGS 7.5-minute series quadrangle maps, these areas have blue overprint. A constant of 10 is added to ST by the NFF program; the user enters the actual value of ST.

Area of forest $(\mathrm{F})$, is the percentage of drainage area, $\mathrm{A}$, that is covered by forests. On USGS 7.5-minute series quadrangle maps, these areas have green overprint. A constant of 10 is added to $\mathrm{F}$ by the NFF program; the user enters the actual value of F.

Hydrologic soil type A (SA), is the percentage of drainage area, $\mathrm{A}$, that is covered by hydrologic soil type A that, when thoroughly wetted, has high infiltration rates (Soil Conservation Service, 1985).

Hydrologic soil type D (SD), is the percentage of drainage area, A, that is covered by hydrologic soil type $\mathrm{D}$ that, when thoroughly wetted, has low infiltration rates (Soil Conservation Service, 1985).

Basin relief (BR), in feet (National Geodetic Vertical Datum of 1929), is the difference between the mean and outlet elevations of the drainage basin. The mean elevation should be determined by the grid-sampling technique. A transparent grid is placed over the map on which the basin boundary is drawn. The elevation is determined at 50 to 100 intersections and the values averaged.

Dillow (1996) provided plates that illustrate the extent of SA and SD. These plates are based on more detailed maps prepared by the Maryland Department of State Planning (1973). A constant of 10 is added to SA and SD by the NFF program; the user enters the actual value of SA and SD.

The regression equations, the average standard errors of prediction, and the equivalent years of record are shown in table 1 . The standard error of prediction is a measure of the accuracy of the regression equations when estimating peak-discharge values for ungaged watersheds similar to watersheds that were used to derive the regression equations. About two thirds of estimates for ungaged sites will have errors less than or equal to the standard errors of prediction. The standard error of prediction increases appreciably when any explana- tory watershed variable is near or beyond the range limits shown in table 2 .

The relation between the BDF and peak discharge for the 100-year and 500year recurrence intervals in the Piedmont hydrologic region is not statistically significant. The BDF is included in all the equations for the Piedmont region to maintain consistency within the equation set.

\section{Improving Estimates With Gaged Data}

Dillow (1996) developed weighting techniques to improve estimates of peak discharge at gaged locations by combining the estimates derived from analysis of gage records with estimates derived from the regression equations. The weights of these two independent estimates are based on the length of the gage record in years $(N)$ and the equivalent years of record $(E Q)$ of the applicable regression equation. The weighted estimate of peak discharge is computed as

$\log Q_{T(G) w}=\frac{N \cdot \log Q_{T(G) s}+E Q \cdot \log Q_{T(G) r}}{N+E Q}$

where

$Q_{T(G) w}$ is the weighted estimate of discharge $Q$ for recurrence interval $\mathrm{T}$ at the streamgaging station,

$Q_{T(G) s}$ is the estimate of $\mathrm{Q}_{\mathrm{T}}$ derived from analysis of the systematic gage records,

$Q_{T(G) r}$ is the estimate of $\mathrm{Q}_{\mathrm{T}}$ derived from application of the appropriate regression equation in table 1,

$N$ is the number of years in the gage record used to compute $Q_{T(G) s}$, and

$E Q$ is the equivalent years of record (table 1).

The accuracy of the weighted discharge estimate, in equivalent years of record, is equal to $N+E Q$. The NFF Program performs these weighting computations. 
Table 1. Flood-peak discharge regression equations and associated statistics for non-tidal streams in Delaware (modified from Dillow, 1996)

$\left[\mathrm{Q}_{\mathrm{T}}\right.$, peak discharge for recurrence interval T, 2 to 500 years, in cubic feet per second; A, drainage area, in square miles; BDF, basin development factor; ST, storage (lakes, ponds, and swamps), in percent; F, forest cover, in percent; SA, hydrologic soil type A, in percent; SD, hydrologic soil type D, in percent; BR, basin relief, in feet]

\begin{tabular}{|c|c|c|}
\hline Regression equation & $\begin{array}{l}\text { Average standard } \\
\text { error of prediction, } \\
\text { in percent }\end{array}$ & $\begin{array}{l}\text { Equivalent years } \\
\text { of record }\end{array}$ \\
\hline \multicolumn{3}{|c|}{$\underline{\text { Piedmont region (37 stations) }}$} \\
\hline $\mathrm{Q}_{2}=2.97 \times 10^{5} \mathrm{~A}^{0.670}(13-\mathrm{BDF})^{-0.764}(\mathrm{ST}+10)^{-2.36}$ & 23 & 6 \\
\hline $\mathrm{Q}_{5}=6.88 \times 10^{5} \mathrm{~A}^{0.607}(13-\mathrm{BDF})^{-0.548}(\mathrm{ST}+10)^{-2.65}$ & 23 & 12 \\
\hline $\mathrm{Q}_{10}=1.08 \times 10^{6} \mathrm{~A}^{0.570}(13-\mathrm{BDF})^{-0.398}(\mathrm{ST}+10)^{-2.83}$ & 25 & 15 \\
\hline $\mathrm{Q}_{25}=1.73 \times 10^{6} \mathrm{~A}^{0.531}(13-\mathrm{BDF})^{-0.223}(\mathrm{ST}+10)^{-3.03}$ & 28 & 18 \\
\hline $\mathrm{Q}_{50}=2.33 \times 10^{6} \mathrm{~A}^{0.507}(13-\mathrm{BDF})^{-0.105}(\mathrm{ST}+10)^{-3.16}$ & 31 & 19 \\
\hline $\mathrm{Q}_{100}=3.05 \times 10^{6} \mathrm{~A}^{0.485}(13-\mathrm{BDF})^{0.004}(\mathrm{ST}+10)^{-3.27}$ & 35 & 19 \\
\hline $\mathrm{Q}_{500}=5.30 \times 10^{6} \mathrm{~A}^{0.440}(13-\mathrm{BDF})^{0.237}(\mathrm{ST}+10)^{-3.52}$ & 45 & 18 \\
\hline \multicolumn{3}{|c|}{$\underline{\text { Coastal Plain region (37 stations) }}$} \\
\hline $\mathrm{Q}_{2}=134 \mathrm{~A}^{0.549}(\mathrm{~F}+10)^{-0.662}(\mathrm{SA}+10)^{-0.394}(\mathrm{SD}+10)^{0.334} \mathrm{BR}^{0.430}$ & 43 & 3 \\
\hline $\mathrm{Q}_{5}=306 \mathrm{~A}^{0.511}(\mathrm{~F}+10)^{-0.840}(\mathrm{SA}+10)^{-0.424}(\mathrm{SD}+10)^{0.392} \mathrm{BR}^{0.552}$ & 41 & 6 \\
\hline $\mathrm{Q}_{10}=596 \mathrm{~A}^{0.490}(\mathrm{~F}+10)^{-0.940}(\mathrm{SA}+10)^{-0.438}(\mathrm{SD}+10)^{0.409} \mathrm{BR}^{0.584}$ & 40 & 10 \\
\hline $\mathrm{Q}_{25}=1,440 \mathrm{~A}^{0.467}(\mathrm{~F}+10)^{-1.06}(\mathrm{SA}+10)^{-0.447}(\mathrm{SD}+10)^{0.418} \mathrm{BR}^{0.593}$ & 38 & 17 \\
\hline $\mathrm{Q}_{50}=2,770 \mathrm{~A}^{0.452}(\mathrm{~F}+10)^{-1.15}(\mathrm{SA}+10)^{-0.446}(\mathrm{SD}+10)^{0.422} \mathrm{BR}^{0.590}$ & 38 & 23 \\
\hline $\mathrm{Q}_{100}=5,230 \mathrm{~A}^{0.439}(\mathrm{~F}+10)^{-1.25}(\mathrm{SA}+10)^{-0.439}(\mathrm{SD}+10)^{0.425} \mathrm{BR}^{0.584}$ & 38 & 30 \\
\hline $\mathrm{Q}_{500}=21,500 \mathrm{~A}^{0.410}(\mathrm{~F}+10)^{-1.47}(\mathrm{SA}+10)^{-0.411}(\mathrm{SD}+10)^{0.428} \mathrm{BR}^{0.564}$ & 39 & 45 \\
\hline
\end{tabular}

Table 2. Range of explanatory variables for which regression equations are applicable in Delaware (modified from Dillow, 1996) [--, data not statistically significant]

\begin{tabular}{|c|c|c|c|c|c|c|c|}
\hline $\begin{array}{l}\text { Hydrologic } \\
\text { study region }\end{array}$ & $\begin{array}{c}\text { Drainage } \\
\text { area, in } \\
\text { square miles }\end{array}$ & $\begin{array}{l}\text { Basin relief, } \\
\text { in feet }\end{array}$ & $\begin{array}{l}\text { Forest cover, } \\
\text { in percent }\end{array}$ & $\begin{array}{l}\text { Hydrologic } \\
\text { soil type A, } \\
\text { in percent }\end{array}$ & $\begin{array}{l}\text { Hydrologic } \\
\text { soil type } D, \\
\text { in percent }\end{array}$ & $\begin{array}{c}\text { Basin } \\
\text { development } \\
\text { factor }\end{array}$ & $\begin{array}{l}\text { Storage } \\
\text { in percent }\end{array}$ \\
\hline Piedmont & 0.37 to 314 & -- & -- & -- & -- & 0 to 10 & 0.000 to 6.100 \\
\hline Coastal Plain & .60 to 113 & 4 to 57 & 8 to 85 & 0 to 100 & 0 to 100 & -- & -- \\
\hline
\end{tabular}

\section{Ungaged Sites Near Gaged Sites on the Same Stream}

Dillow (1996) also showed how the weighted estimate for peak discharge at a gaged site can be used to improve estimates of peak discharge for an ungaged site on the same stream with a drainage between 50 and 150 percent of the drainage area of the gaged site. The regression estimate for the ungaged site is multiplied by an adjustment factor, which is computed as

$$
A F=R-\frac{\Delta A(R-1)}{0.5 A_{\text {gaged }}},
$$

where
$A F$ is the adjustment factor,

$\Delta A$ is the absolute difference in drainage area, $\mid \mathrm{A}_{\text {gaged }}-\mathrm{A}_{\text {un- }}$ gaged ${ }^{l}$, and

$R$ is the ratio of the weighted peak discharge estimate to the regression estimate at the gaged site, $Q_{T(G) w} / Q_{T(G) r}$

The equations should be used without adjustment where the drainage area of the ungaged site is not within 50 to 150 percent of the drainage area of the gaged site.

-Prepared by Luis A. Fuste and Robert R. Mason

\section{References}

Dillow, J.J.A., 1996, Technique for estimating magnitude and frequency of peak flows in Delaware: U.S. Geological Survey Water-Resources Investigations Report 95-4153, 26 p.

Jennings, M.E., Thomas, W.O., Jr., and Riggs, H.C., comps., 1994, Nationwide summary of U.S. Geological Survey regional regression equations for estimating magnitude and frequency of floods for ungaged sites, 1993: U.S. Geological Survey WaterResources Investigations Report 94-4002, 196 p. 
Maryland Department of State Planning, 1973, Natural soil groups technical report: Maryland Department of State Planning Publication No. 199, 153 p. Sauer, V.B., Thomas, W.O., Jr., Stricker, V.A., and Wilson, K.V., 1983, Flood characteristics of urban watersheds in the United States: U.S. Geological Survey Water-Supply Paper 2207, $63 \mathrm{p}$.

Soil Conservation Service, 1985, Soil Conservation Service National Engineering Handbook, Sec. 4, Hydrology: U.S. Department of Agriculture.

\section{For more information contact:}

U.S. Geological Survey Office of Surface Water 415 National Center Reston, Virginia 20192 (703) 648-5301

USGS hydrologic analysis software is available for electronic retrieval through the World Wide Web (WWW) at http://water.usgs.gov/software/ and through anonymous File Transfer Protocol (FTP) from water.usgs.gov (directory: /pub/software). The WWW page and anonymous FTP directory from which the National Flood-Frequency software and user documentation can be retrieved are http://water.usgs.gov/software/nff.html and

/pub/software/surface_water/nff, respectively.

Additional earth science information is available from the USGS through the WWW at http://www.usgs.gov/ or by calling 1-888-ASK-USGS. 